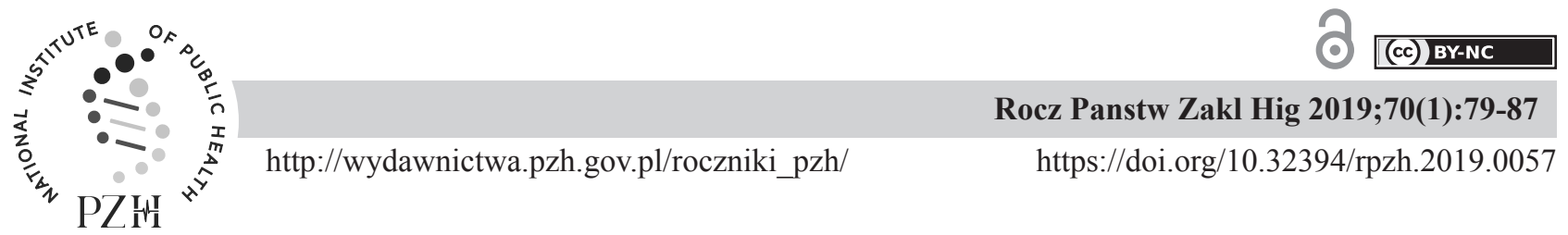

ORIGINAL ARTICLE

\title{
WHAT ARE THE DIETS OF PATIENTS BEFORE BARIATRIC SURGERY?
}

\author{
Natalia Komorniakl, Viktoria Hawryłkowicz', Agnieszka Dziedzic ${ }^{l}$, \\ Karolina Skonieczna-Żydecka ${ }^{1}$, Ewa Stachowska ${ }^{1}$, Matgorzata Szczuko ${ }^{1}$
}

${ }^{1}$ Department of Biochemistry and Human Nutrition, Pomeranian Medical University in Szczecin, Poland

\begin{abstract}
Background. Obesity is regarded as the most common disease of affluence, gradually getting an epidemic status.

Objective. The aim of the study was to assess the frequency of consumption of selected food products among the patients qualified for bariatric surgery, together with the analysis of the potential effect of the diet on the development of obesity in examined group of people.

Material and Methods. The study involved 57 patients qualified for bariatric treatment of obesity. A standardized food frequency questionnaire (FFQ) was used and anthropometric measurements were performed.

Results. In examined group of people, along with increasing BMI, the frequency of cheeses consumption decreased, whereas the frequency of consumption of vegetable and fruit - vegetable juices increased. In addition to that, it was observed that with higher frequency of consumption of animal fat (lard, bacon) and beer, the value of WHR increased, whereas the frequency of consumption of dairy products was in direct proportion to body weight of examined people. It was also noted that people living in the country consumed fruits and potatoes significantly more often than people living in the city, and that people with higher education significantly more often ate coarse grits, high quality meats and fatty fish, as compared to people with vocational training.

Conclusions. Inappropriate selection of food products and numerous dietary mistakes made by the patients directly contributed to the development of extreme obesity. The patients prepared for bariatric surgery should receive a dietician support during the preparation for the procedure and afterwards, later in life, in order to maintain a reduced body weight after the surgery.
\end{abstract}

Key words: bariatric surgery, feeding behavior, obesity, diet, body mass index, BMI

\section{STRESZCZENIE}

Wprowadzenie. Otyłość jest uznawana za najczęściej występującą chorobę cywilizacyjną, stopniowo przybierającą postać epidemii.

Cel. Celem pracy była ocena częstości spożycia wybranych produktów spożywczych wśród pacjentów zakwalifikowanych do operacji bariatrycznej wraz z określeniem potencjalnego wpływu sposobu odżywiania na rozwój otyłości w badanej grupie osób.

Materiał i Metody. W badaniu wzięło udział 57 pacjentów zakwalifikowanych do chirurgicznego leczenia otyłości. Wykorzystano standaryzowany kwestionariusz częstości spożycia (FFQ) oraz wykonano pomiary antropometryczne.

Wyniki. W badanej grupie osób wraz ze wzrostem wskaźnika BMI spadało spożycie serów, a jednocześnie zwiększała się częstość spożywania soków warzywnych i warzywno-owocowych. Dodatkowo zaobserwowano, że wraz ze wzrostem częstotliwości spożycia tłuszczów zwierzęcych (smalcu, słoniny) oraz piwa zwiększeniu ulegała wartość wskaźnika WHR, natomiast częstość spożycia produktów nabiałowych była wprost proporcjonalna do masy ciała badanych osób. Odnotowano także, iż mieszkańcy wsi istotnie częściej niż mieszkańcy dużych miast spożywali owoce oraz ziemniaki, a także że osoby z wyższym wykształceniem istotnie częściej sięgali po kasze gruboziarniste, wędliny wysokogatunkowe oraz thuste gatunki ryb w odniesieniu do osób z wykształceniem zawodowym.

Wnioski. Nieodpowiedni dobór produktów spożywczych oraz liczne błędy żywieniowe popełniane przez pacjentów, bezpośrednio przyczyniły się do rozwoju otyłości olbrzymiej. Pacjenci przygotowywani do operacji bariatrycznej powinni otrzymać wsparcie dietetyka podczas przygotowania do zabiegu oraz w celu utrzymania zredukowanej po operacji masy ciała, w kolejnych etapach życia.

Słowa kluczowe: chirurgia bariatryczna, nawyki żywieniowe, otyłość, dieta, wskaźnik masy ciała, BMI

Corresponding author: Małgorzata Szczuko, Zakład Biochemii i Żywienia Człowieka, ul. Broniewskiego 24, 71-460 Szczecin, tel. +48 91441 4806, Fax: +48 91441 4807, e-mail: malgorzata.szczuko@pum.edu.pl

(C) Copyright by the National Institute of Public Health - National Institute of Hygiene 


\section{INTRODUCTION}

Obesity is regarded as the most common disease of affluence, gradually getting an epidemic status [38]. According to the World Health Organization (WHO) the percentage of overweight and obese people increased three-fold compared to the year 1975. It means that 1.9 milliard people in the world are overweight, including more than 650 million suffering from obesity [39]. Focusing on the situation in Poland only, the study WOBASZ II shows that in the years $2013-2014$, in comparison with the years 2003 - 2005, there was an increase in body mass index - BMI. It was also noted that the percentage of adults with proper waist circumference significantly decreased in case of both sexes. In the study the incidence of excessive weight reached $43.2 \%$ in men and $30.5 \%$ in women, whereas obesity was recognized in $24.4 \%$ and $25 \%$ men and women, respectively. Abdominal obesity (defined as waist circumference larger than $94 \mathrm{~cm}$ in men and 80 $\mathrm{cm}$ in women) was noted in $27.2 \%$ men and $21.7 \%$ woman [34]. Etiopathogenesis of this chronic noninfectious disease relates to the excessive accumulation of adipose tissue in a body. Primary obesity, which is the most common type of obesity, occurring mainly in developed countries and less common in developing ones, results from a positive energy balance, caused by many environmental factors contributing to unhealthy lifestyle, including nutrition [36]. Accumulation of fatty tissue is also facilitated by irregular consumption of meals with long intervals between them, leading to disturbances in the function of endocrine system, especially in the release of insulin and leptin, resulting in insulin- and leptin-resistance [14]. Additionally, it was proved that eating foods at irregular intervals has a negative effect on satiety and hunger centre due to frequent consumption between the meals and at night [21]. This, in turn, increases the accumulation of energy storage in form of adipocytes. A crucial role in the formation of primary obesity is also played by improper thermal treatment of food products (frying) and low physical activity [3], which is related to sedentary lifestyle, common use of transport and developing urbanization [36]. Another factors contributing to increasing body mass are also the lack of time on the preparation of homemade meals, positively correlated with civilisation development [36], and increasing level of stress, which is a factor releasing the behaviours related to excessive consumption of food to lower emotional tension [17; 21]. Important aspect linked to the development of obesity is the imbalance in the composition of gut microflora, termed as dysbiosis. A typical "western" diet - high in protein, saturated fatty acids and simple sugars and lacking in dietary fibre, contributes to lowering the number of Bifidobacterium species. Additionally, in obese people the domination of Gram-positive bacteria is observed, e.g. Clostridium and Mollicutes species. Mollicutes especially have the ability to obtain energy from food waste, which is then stored in fatty tissue. A compromised intestinal barrier and the translocation of the bacteria to bloodstream lead to a generalized inflammatory reaction in the body [23].

Excessive body mass, including fatty tissue, significantly lowers the health and functionality of the whole organism. Obesity increases the risk of dyslipidaemia, hyperinsulinemia, insulin resistance, heart attack, ischemic stroke and numerous tumours, including digestive tract and hormone-dependent tumours [18]. Additionally, the most common diseases accompanying obesity are type 2 diabetes, ischemic heart disease, atherosclerosis, high blood pressure and arthritis and bone and joints diseases [36], gout, non-alcoholic fatty liver disease (NAFLD) and cholelithiasis [26;32]. All the complications of obesity mentioned above have a negative effect on psychic functions and may strengthen low selfesteem often observed in obese people. Numerous complexes and the tendency to isolate oneself from the environment and to avoid social contacts may trigger the development of extreme obesity [33].

The methods used to treat obesity include the modification of lifestyle, involving balanced diet and intermediate physical activity, and increased selfacceptance through expanding own interests and hobbies. Moreover, pharmacological treatment and in many cases also psychological or psychic support are used, whereas surgical treatment is offered in case of patients with extreme obesity [11-12;20]. Bariatric surgery is available for use in patients with BMI exceeding $40 \mathrm{~kg} / \mathrm{m}^{2}$, or $35 \mathrm{~kg} / \mathrm{m}^{2}$ with accompanying diseases, and includes restrictive, adsorption limiting and hybrid techniques. The effects of the treatment are visible shortly after the procedure and include, besides body mass reduction, an improvement in the course of, or even complete recovery from, accompanying diseases, e.g. type 2 diabetes. When making a decision whether to use this method of treatment one should consider that the surgery is just one part of the complex obesity treatment process, and the therapeutic group, both before and after the procedure, should include a bariatric surgeon, a general practitioner, a dietician, a psychologist and a nurse [22]. It seems that due to numerous health consequences of bariatric procedures and the risk of developing/strengthening nutritional deficiencies [20] the decision to use this method should be well-justified.

Due to increasing epidemic of obesity the frequency of bariatric procedures increases. The aim of the work was to assess of the frequency of consumption of selected food products among the candidates for surgical obesity treatment, together with the analysis of the potential effect of the diet on the development of obesity in examined group of people. 


\section{MATERIAL AND METHODS}

Test group. The study involved 57 patients (30 women and 27 men) of Bariatric Clinic of the Independent Public Voivodeship Complex Hospital in Szczecin - Zdunowo. Anthropometric characteristics of examined people (the measurements with the accuracy $0.1 \mathrm{~kg}$ and $0.5 \mathrm{~cm}$ ) are presented in Table 1 . The majority of patients $(58 \%)$ were the citizens of large cities, with secondary education (46\%) and worked full time (54\%) (Table 2). As much as $80.7 \%$ of examined people confirmed that they did not undertake any physical activity and led a sedentary lifestyle.
Table 1. Anthropometric data from examined people

\begin{tabular}{|l|c|c|c|c|}
\hline \multicolumn{1}{|c|}{ Parameter } & Women & Men & Total & $\mathrm{p}$ \\
\hline $\mathrm{n}$ & 30 & 27 & 57 & \\
\hline Age [years] & $46.3 \pm 11.8$ & $47.4 \pm 10$ & $47 \pm 10.9$ & 0.78 \\
\hline Body mass [kg] & $131.6 \pm 17.1$ & $141.8 \pm 22.9$ & $136.4 \pm 20.5$ & 0.06 \\
\hline BMI $\left[\mathrm{kg} / \mathrm{m}^{2}\right]$ & $46.6 \pm 5.8$ & $44.4 \pm 6.6$ & $45.5 \pm 6.2$ & 0.18 \\
\hline WHR & $0.97 \pm 0.05$ & $1.09 \pm 0.06$ & $1.03 \pm 0.08$ & 0.0001 \\
\hline
\end{tabular}

Table 2. Socioeconomic status vs sexes

\begin{tabular}{|c|c|c|c|c|}
\hline Parameter & Women $[\%]$ & Men $[\%]$ & Total [\%] & $\mathrm{p}$ \\
\hline \multicolumn{5}{|c|}{ Place of living } \\
\hline City $>100000$ citizens & 65 & 48.15 & 57.9 & \multirow{3}{*}{0,31} \\
\hline City from 10000 to 100000 citizens & 20 & 37.04 & 28.1 & \\
\hline Country/small town up to 10000 citizens & 15 & 14.8 & 14.04 & \\
\hline \multicolumn{5}{|c|}{ Education } \\
\hline Primary & 2.5 & 7.4 & 5.3 & \multirow{4}{*}{0,89} \\
\hline Secondary & 47.5 & 48.1 & 46.6 & \\
\hline High & 25 & 18.5 & 22.8 & \\
\hline Vocational & 25 & 25.9 & 26.3 & \\
\hline \multicolumn{5}{|c|}{ Source of income } \\
\hline Full-time job & 56.67 & 51.9 & 54.4 & \multirow{5}{*}{0,42} \\
\hline Part-time job & 0 & 7.41 & 3.51 & \\
\hline Unemployed & 20 & 14.8 & 17.5 & \\
\hline Pension & 20 & 25.93 & 22.8 & \\
\hline Other, e.g. civil contract & 3.33 & 0 & 1.75 & \\
\hline
\end{tabular}

Questionnaire. A standardized food frequency questionnaire (FFQ) was used in the study. Ranks from the questionnaire were translated into the frequency of consumption of selected groups of products according to the following scheme:

- Never or hardly ever - 0 times a day

- Once a month or less frequent - 0.025 times a day

- Several times a month - 0.1 times a day

- Several times a week - 0.571 times a day

- Every day - once a day

- A few times a day - twice a day

\section{Statistical analysis}

Obtained results were statistically analysed using StatView 5.0 (SAS Institute Inc. Cary, NC, USA). The normality of the distribution was tested with ShapiroWilk test. Statistical significance of anthropometric data depending on the sex was analysed using variance analysis ANOVA. Pearson's $\chi^{2}$ test was used to analyse the relations between sociodemographic variables. Continuous variables were characterized by mean and standard deviation and in case of qualitative variables the results were given in percentage. In case of, correlations between frequency of eating food products and place of residence, education, source of income variance analysis ANOVA was used. Correlations between frequency of eating food products and age, BMI analysed using Pearson method. Correlations between frequency of eating and body mass and WHR analysed using Spearman method. The level of significance was $\mathrm{p}<0,05$.

\section{RESULTS}

The frequency of consumption of food products is given in Table 3. In this study the frequency of products' consumption was not dependent on the $\operatorname{sex}(p>0.05)$. It was, however, observed that the consumption of salty snacks $(\mathrm{r}=-0.322 ; \mathrm{p}=0.01)$ was correlated with age. It was also noted that along with the increase of BMI the intake of cheeses decreased $(r=-0.333 ; p=0.01)$ and, at the same time, the frequency of consumption of vegetable and fruit - vegetable juices were higher $(\mathrm{r}=0.316 ; \mathrm{p}=0.02)$. Additionally, it was observed that with increased frequency of consumption of animal fats (lard, bacon, $\mathrm{r}=0.331 ; \mathrm{p}=0.01)$ and beer $(\mathrm{r}=0.322$; $\mathrm{p}=0.02)$ the value of WHR increased. The frequency of consumption of flavoured quarks $(p=0.01)$ was directly proportional to body mass of examined people. The relations between the frequency of consumption of products and sociodemographic conditions of examined group of people are presented in Tables 4-6. 


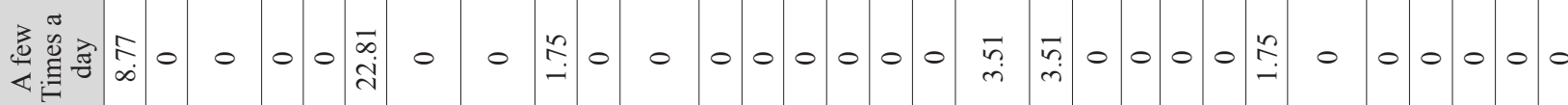

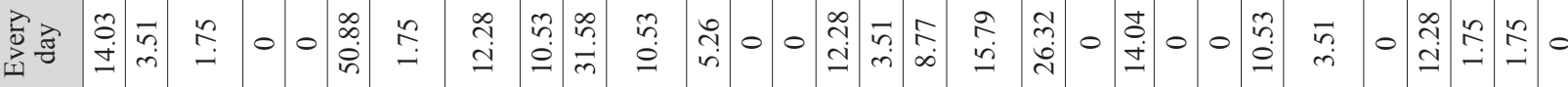

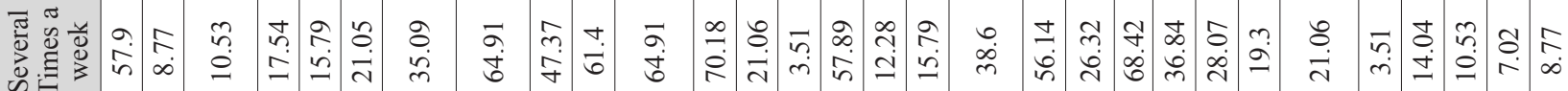

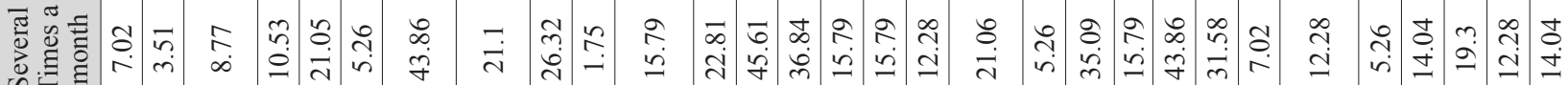

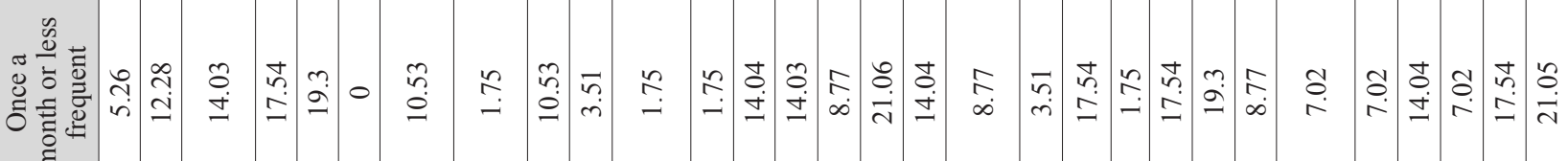

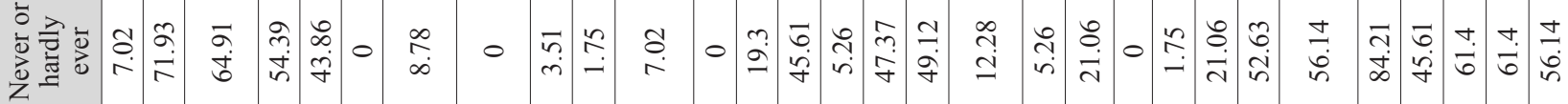

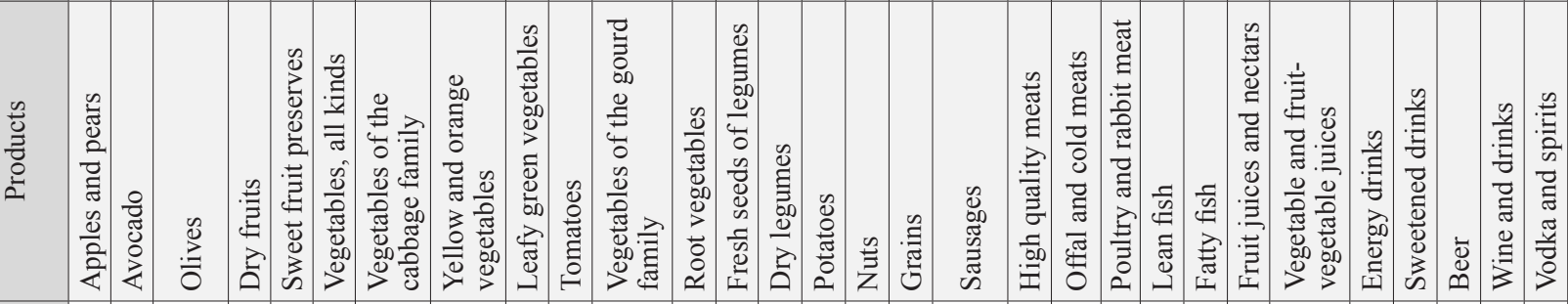

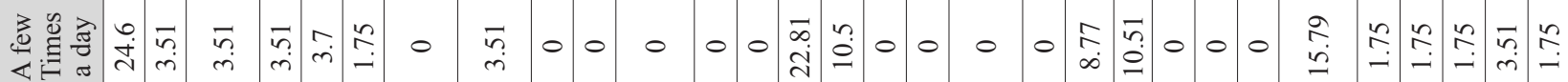

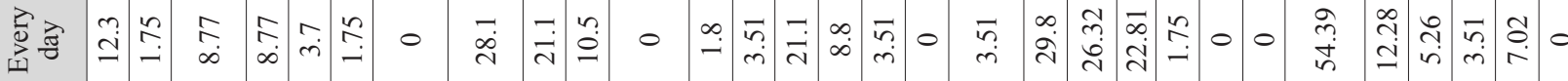

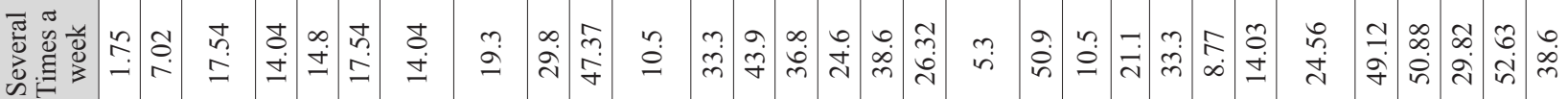

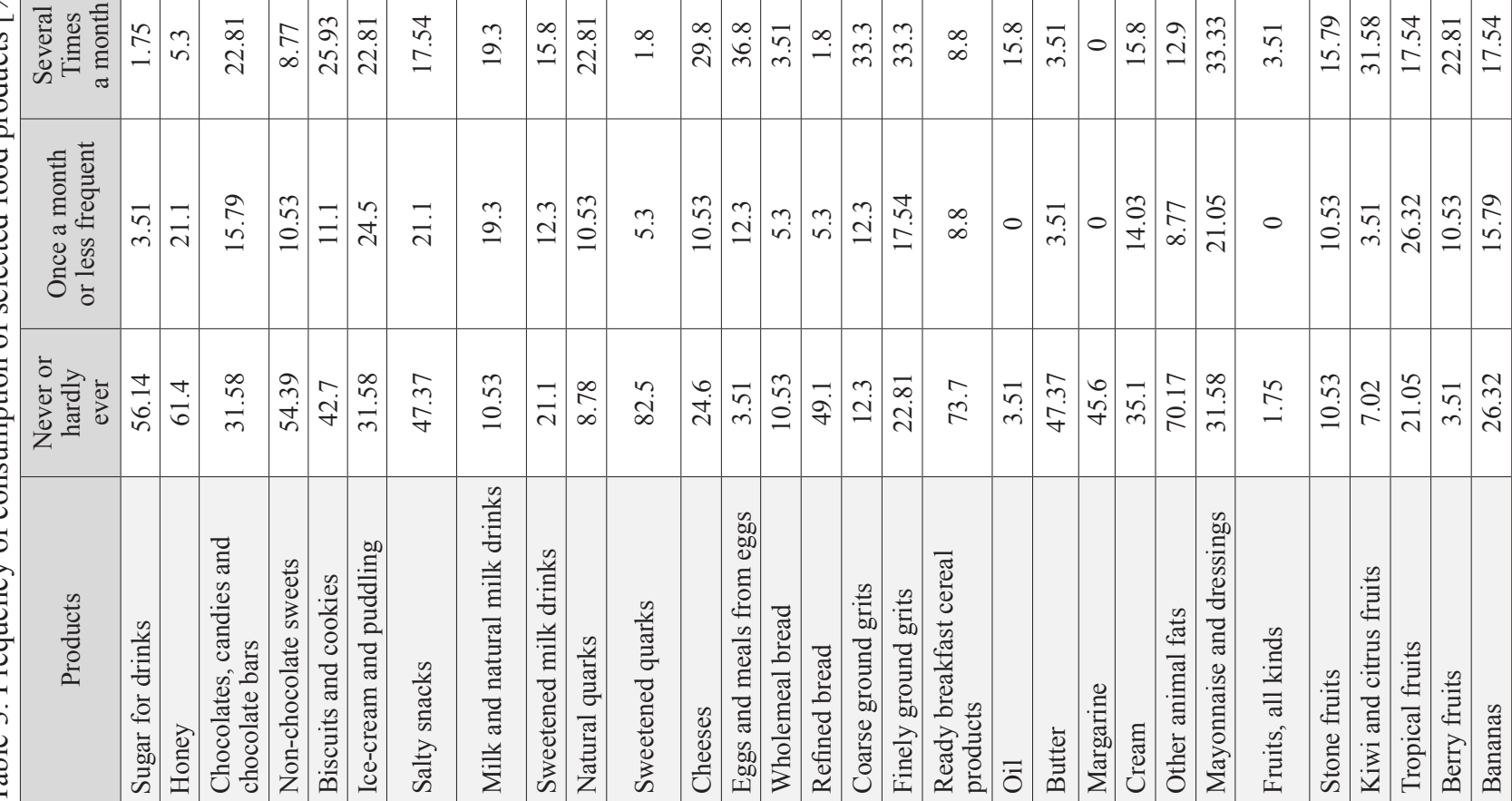


Table 4. Relations between the place of living and the frequency of consumption expressed as a mean value and standard deviation

\begin{tabular}{|c|c|c|c|c|}
\hline Frequency of consumption & $\mathrm{DM}$ & MM & W & $\mathrm{p}$ \\
\hline White bread & $0.27 \pm 0.44$ & $0.67 \pm 0.85$ & $0.71 \pm 0.64$ & 1) 0.034 \\
\hline Fruits, all kinds & $0.94 \pm 0.54$ & $1.18 \pm 0.6$ & $1.5 \pm 0.54$ & 2) 0.013 \\
\hline Kiwi and citrus fruits & $0.31 \pm 0.3$ & $0.53 \pm 0.46$ & $0.51 \pm 0.29$ & 1) 0.048 \\
\hline Tropical fruits & $0.18 \pm 0.29$ & $0.45 \pm 0.5$ & $0.25 \pm 0.27$ & 1) 0.017 \\
\hline Bananas & $0.2 \pm 0.27$ & $0.43 \pm 0.49$ & $0.27 \pm 0.25$ & 1) 0.033 \\
\hline \multirow{2}{*}{ Dry legumes } & \multirow{2}{*}{$0.5 \pm 0.5$} & \multirow{2}{*}{$0.11 \pm 0.18$} & \multirow{2}{*}{$0.01 \pm 0.04$} & 1) 0.044 \\
\hline & & & & 3) 0.030 \\
\hline Potatoes & $0.44 \pm 0.3$ & $0.43 \pm 0.33$ & $0.68 \pm 0.2$ & 2) 0.047 \\
\hline Lean fish & $0.23 \pm 0.23$ & $0.24 \pm 0.23$ & $0.43 \pm 0.26$ & 2) 0.03 \\
\hline \multicolumn{5}{|l|}{ Other products - NS $(p>0,05)$} \\
\hline \multicolumn{5}{|c|}{$\begin{array}{l}\text { DM-city above } 100000 \text { citizens; } M M-\text { city from } 10000 \text { to } 100000 \text { citizens; } W \text { - small town up to } 10000 \text { citizens or a village; } \\
\text { Statistical significance }(p) \text { : } \\
\text { 1) } D M \text { vs } M M \\
\text { 2) } D M \text { vs } W \\
\text { 3) } M M \text { vs } W \\
\text { NS- statistically insignificant. }\end{array}$} \\
\hline
\end{tabular}

Table 5. Relations between the education and the frequency of consumption expressed as a mean value and standard deviation

\begin{tabular}{|c|c|c|c|c|c|}
\hline Frequency of consumption & Primary & Secondary & Higher & Vocational & $\mathrm{p}$ \\
\hline \multirow{2}{*}{ Honey } & \multirow{2}{*}{$0.0 \pm 0.0$} & \multirow{2}{*}{$0.076 \pm 0.18$} & \multirow{2}{*}{$0.39 \pm 0.77$} & \multirow{2}{*}{$0.073 \pm 0.26$} & 4) 0.024 \\
\hline & & & & & 6) 0.041 \\
\hline Ice-cream and pudding & $0.33 \pm 0.06$ & $0.24 \pm 0.29$ & $0.29 \pm 0.58$ & $0.03 \pm 0.04$ & 6) 0.044 \\
\hline Sweetened milk drinks & $0.53 \pm 0.49$ & $0.28 \pm 0.37$ & $0.58 \pm 0.38$ & $0.45 \pm 0.38$ & 4) 0.027 \\
\hline Eggs and meals from eggs & $0.38 \pm 0.33$ & $0.31 \pm 0.26$ & $0.49 \pm 0.33$ & $0.24 \pm 0.24$ & 6) 0.028 \\
\hline Margarine & $0.52 \pm 0.5$ & $0.56 \pm 0.63$ & $0.25 \pm 0.45$ & $0.81 \pm 0.75$ & 6) 0.026 \\
\hline Cream & $0.38 \pm 0.33$ & $0.28 \pm 0.31$ & $0.08 \pm 0.16$ & $0.22 \pm 0.26$ & 4) 0.033 \\
\hline \multirow{3}{*}{ Stone fruits } & \multirow{3}{*}{$1.05 \pm 0.83$} & \multirow{3}{*}{$0.48 \pm 0.34$} & \multirow{3}{*}{$0.36 \pm 0.26$} & \multirow{3}{*}{$0.44 \pm 0.54$} & 1) 0.03 \\
\hline & & & & & 2) 0.014 \\
\hline & & & & & 3) 0.025 \\
\hline \multirow{2}{*}{ Coarse ground grits } & \multirow{2}{*}{$0.38 \pm 0.33$} & \multirow{2}{*}{$0.2 \pm 0.23$} & \multirow{2}{*}{$0.49 \pm 0.26$} & \multirow{2}{*}{$0.25 \pm 0.32$} & 4) 0.003 \\
\hline & & & & & 6) 0.024 \\
\hline \multirow{2}{*}{ Olives } & \multirow{2}{*}{$0.0 \pm 0.0$} & \multirow{2}{*}{$0.07 \pm 0.22$} & \multirow{2}{*}{$0.25 \pm 0.29$} & \multirow{2}{*}{$0.02 \pm 0.04$} & 4) 0.014 \\
\hline & & & & & 6) 0.004 \\
\hline \multirow{3}{*}{ Sweet fruit preserves } & \multirow{3}{*}{$0.41 \pm 0.27$} & \multirow{3}{*}{$0.12 \pm 0.2$} & \multirow{3}{*}{$0.11 \pm 0.22$} & \multirow{3}{*}{$0.05 \pm 0.15$} & 1) 0.0163 \\
\hline & & & & & 2) 0.0162 \\
\hline & & & & & 3) 0.004 \\
\hline Potatoes & $0.41 \pm 0.27$ & $0.47 \pm 0.3$ & $0.3 \pm 0.34$ & $0.62 \pm 0.25$ & 6) 0.007 \\
\hline \multirow{2}{*}{ Grains } & \multirow{2}{*}{$0.22 \pm 0.31$} & \multirow{2}{*}{$0.12 \pm 0.22$} & \multirow{2}{*}{$0.44 \pm 0.46$} & \multirow{2}{*}{$0.12 \pm 0.28$} & 4) 0.004 \\
\hline & & & & & 6) 0.009 \\
\hline High quality meats & $0.57 \pm 0.0$ & $0.58 \pm 0.34$ & $0.9 \pm 0.63$ & $0.63 \pm 0.15$ & 4) 0.023 \\
\hline \multirow{2}{*}{ Lean fish } & $057+00$ & $024+024$ & $028+026$ & $02+023$ & 1) 0.026 \\
\hline & $0.51+0.0$ & $0.2+1.0 .27$ & $0.20 \pm 0.20$ & $0.2+0.20$ & 3) 0.017 \\
\hline Fatty fish & $0.38 \pm 0.33$ & $0.17 \pm 0.22$ & $0.32 \pm 0.26$ & $0.1 \pm 0.19$ & 6) 0.017 \\
\hline Beer & $0.0 \pm 0.0$ & $0.07 \pm 0.15$ & $0.24 \pm 0.35$ & $0.1 \pm 0.2$ & 4) 0.031 \\
\hline Wine and drinks & $001+0.01$ & $003+011$ & $022+032$ & $005+015$ & 4) 0.005 \\
\hline ville allu पाIIKs & $0.01+0.01$ & $0.05 \pm 0.11$ & $0.22 \pm 0.52$ & $0.05+0.15$ & 6) 0.017 \\
\hline Other products - NS $(p>0.05)$ & & & & & \\
\hline $\begin{array}{l}\text { Statistical significance (p): } \\
\text { 1) Primary vs Secondary } \\
\text { 2) Primary vs Higher } \\
\text { 3) Primary vs Vocational }\end{array}$ & & $\begin{array}{l}\text { 4) } \mathrm{Sec} \\
\text { 5) } \mathrm{Sec} \\
\text { 6) } \mathrm{Hig} \\
\mathrm{NS}-\text { s }\end{array}$ & $\begin{array}{l}\text { vs Higher } \\
\text { vs Vocationa } \\
\text { Vocational } \\
\text { cally insignific }\end{array}$ & & \\
\hline
\end{tabular}


Table 6. Relation between the source of income and the frequency of consumption expressed as a mean value and standard deviation

\begin{tabular}{|c|c|c|c|}
\hline Source of income & Food products & Frequency of consumption & $\mathrm{p}$ \\
\hline \multirow{2}{*}{ Part-time job vs civil contract } & Stone fruits & $0.34 \pm 0.33$ vs 2.0 & 0.001 \\
\hline & Sweet fruit preserves & $0.05 \pm 0.07$ vs 0.57 & 0.04 \\
\hline Part-time job vs unemployed & Milk and natural milk drinks & $1.29 \pm 1.01$ vs $0.48 \pm 0.46$ & 0.04 \\
\hline \multirow{4}{*}{ Part-time job vs full-time job } & Milk and natural milk drinks & $1.29 \pm 1.01$ vs $0.41 \pm 0.42$ & 0.02 \\
\hline & Flavoured quarks & $0.3 \pm 0.39$ vs $0.04 \pm 0.15$ & 0.048 \\
\hline & Butter & $1.5 \pm 0.71$ vs $0.43 \pm 0.46$ & 0.02 \\
\hline & Fruit juices and nectars & $1.00 \pm 1.41$ vs $0.25 \pm 0.35$ & 0.01 \\
\hline \multirow{2}{*}{ Part-time job vs pension } & Butter & $1.5 \pm 0.71$ vs $0.39 \pm 0.76$ & 0.02 \\
\hline & Fruit juices and nectars & $1.00 \pm 1.41$ vs $0.05 \pm 0.16$ & 0.002 \\
\hline \multirow{2}{*}{ Civil contract vs unemployed } & Ready breakfast cereals & 0.57 vs $0.1 \pm 0.01$ & 0.01 \\
\hline & Stone fruits & 2.0 vs $0.40 \pm 0.34$ & 0.00 \\
\hline \multirow{3}{*}{ Civil contract vs full-time job } & Ready breakfast cereals & 0.57 vs $0.06 \pm 0.21$ & 0.02 \\
\hline & Stone fruits & 2.0 vs $0.41 \pm 0.31$ & 0.00 \\
\hline & Sweet fruit preserves & 0.57 vs $0.09 \pm 0.17$ & 0.02 \\
\hline \multirow{3}{*}{ Civil contract vs pension } & Natural quarks & 1.0 vs $0.33 \pm 0.32$ & 0.049 \\
\hline & Stone fruits & 2.0 vs $0.58 \pm 0.55$ & 0.001 \\
\hline & Sweet fruit preserves & 0.57 vs $0.11 \pm 0.21$ & 0.03 \\
\hline \multirow{4}{*}{ Unemployed vs full-time job } & Finely ground grits & $0.34 \pm 0.27$ vs $0.17 \pm 0.23$ & 0.03 \\
\hline & Berry fruits & $0.7 \pm 0.48$ vs $0.37 \pm 0.30$ & 0.03 \\
\hline & Potatoes & $0.63 \pm 0.35$ vs $0.41 \pm 0.29$ & 0.04 \\
\hline & Offals and cold meats & $0.33 \pm 0.28$ vs $0.15 \pm 0.22$ & 0.03 \\
\hline \multirow{3}{*}{ Unemployed vs pension } & Finelt ground grits & $0.34 \pm 0.27$ vs $0.14 \pm 0.19$ & 0.04 \\
\hline & Root vegetables & $0.57 \pm 0.20$ vs $0.35 \pm 0.31$ & 0.03 \\
\hline & Fruit juices and nectars & $0.44 \pm 0.43$ vs $0.05 \pm 0.16$ & 0.02 \\
\hline Full-time job vs pension & Fresh seeds of legumes & $0.12 \pm 0.16$ vs $0.31 \pm 0.28$ & 0.01 \\
\hline \multicolumn{4}{|c|}{ Other products $-\mathrm{NS}(\mathrm{p}>0.05)$} \\
\hline
\end{tabular}

\section{DISCUSSION}

Performed study clearly shows that the diets of obese patients, expressed as the frequency of consumption of specific food products, are different from the assumptions of balanced nutrition. It turns out that depending on the place of living of the patients there are significant differences in frequency of consumption of specific products. Among the people living in smaller towns and in the country, there was significantly higher intake of starchy foods and lean fish species in comparison to citizens of large agglomerations. This seems to be in agreement with the data of the Central Statistical Office (CSO) [27] which stated that at the end of 2014 in Poland, irrespective of the sex, an excessive body mass was relatively more often observed in people living in the country than in the cities. In NHANES study performed in USA (2005 -2008 ) it was proved that the incidence of obesity was higher among the people living in the country $-39.6 \%$ than in the people living in the cities $-33.4 \%$ [2]. High consumption of refined grain products among the people of smaller agglomerations undoubtedly contributes to the occurrence of obesity. The stage of grains refinement shows a negative correlation with their content of B group vitamins and magnesium, iron, copper or zinc [15]. Additionally, it was proved that the consumption of refined grains is directly proportional to the accumulation of subcutaneous and visceral adipose tissue [24].

In this study the majority of the patients were living in big cities. This might result from higher awareness of the citizens of larger agglomerations of the negative health implications of obesity, as well as from their higher economic status, which causes that they more often seek medical help than people living in the country. CSO data suggest that higher education correlates with higher economic status and that the citizens of the cities have higher income than people living in the country $[5,29]$. In this study it was noted that the people with higher education significantly more often consumed wholegrain products, grains and fatty fish species (containing omega 3 fatty acids and vitamin D) in comparison to people with vocational training. It seems that highly educated people made better choices due to their more accurate knowledge on pro-healthy properties of food. Wholegrain food products selected by them are the source of dietary fibre, which shortens the intestinal passage of food, prevents constipation and the development of some diseases [25]. Dietary fibre present in wholegrain products is also the nutrient for natural intestinal microflora [16], thus its consumption is potentially linked to increased concentration of short-chained fatty acids (SCFAs) $[10$; 37], vitamins K, B12, B6, B1 and folic acid, and also to proper function of intestinal barrier $[10 ; 16]$. 
More frequent intake of wholemeal bread, rice and pasta and coarse ground grains contributes to lowering the levels of LDL cholesterol and triacylglycerols [9]. Moreover, it regulates the release of insulin and thus supports the maintenance of proper glycaemia and prevents the development of type 2 diabetes [28] and obesity [35].

Interestingly, in this study the highest consumption of fatty fish species was noted in group of people with primary education. Fatty fish supply precious polyunsaturated fatty acids (PUFA). The studies on animals and people showed that the consumption of PUFA is in inverse proportion to the risk of visceral obesity [4]. These acids affect the reduction of appetite and improve the circulation, which helps to maintain proper level of nutrition for skeletal muscles. They also cause changes in genes expression leading to increased energy expenditure, potentiated fats oxidation processes, decreased fatty tissue deposits and increased fat-free body mass [4]. It should be, however, remembered that the majority of patients obtained secondary education, which was related to lower intake of both wholegrain products and those rich in omega- 3 fatty acids, which, together with simultaneous low consumption of vegetables and fruits (the consumption of vegetables a few times a day was declared by only $23 \%$ respondents, and fruits $-16 \%$ respondents) can be regarded as a significant factor related to both pathogenesis and development of obesity. It should also be stressed that people with higher education consumed significantly higher amounts of sweets and sweetened dairy products, which had, in this study, an important influence on patients' body weight. Due to a high glycaemic index and high content of sugar and trans fatty acids (TFA), sweets and salty snacks should be consumed sporadically or totally eliminated from the diet. Their frequent consumption contributes to excessive body weight, increased level of glucose and triglycerides in blood and higher risk of the development of type 2 diabetes, cardiovascular diseases and metabolic syndrome [13]. TFA increase the ratio of total cholesterol to HDL cholesterol and the level of lipoprotein in blood [19].

In this study, an important correlations were noted regarding alcohol consumption. Wine and drinks were consumed significantly more often by people with higher education, which is correlated with higher income [29]. Similar relation was observed for beer, whose frequency of intake additionally proportionally increased with increased WHR of examined people. Studies show that moderate consumption of red wine may protect against cardiovascular diseases, atherosclerosis, high blood pressure, selected tumours, metabolic syndrome and type 2 diabetes. It is caused by the presence of polyphenols, such as resveratrol, and anthocyanins, flavonols and catechins [1]. Thus, the effect depends on the frequency of consumption, the amount and quality of consumed drink. In case of beer and spirits the negative results of their consumption definitely dominate. Beer, due to its very high glycaemic index, increases the appetite and thus facilitates the development of obesity. Moreover, chronic and excessive consumption of alcohol may lead to the loss of control over the habit due to addiction, as well as contribute to the damage of internal organs, especially chronic pancreatitis and liver steatosis, inflammation or even cirrhosis [6].

When discussing the frequency of consumption of food products among the candidates for surgical obesity treatment one should also consider dairy products. Undoubtedly, they are a good source of protein and easily absorbable calcium, which are essential for proper function of the body. Singh et al. described a positive effect of dairy protein on the microbiome [31]. Fermented milk drinks, as they contain lactic acid bacteria, have a positive effect on the body. Their consumption is negatively correlated with the presence of pathogenic Bacteroides fragilis and Clostridium perfringens and positively correlated with the numbers of Bifidobacterium and Lactobacillus. Appropriate contents of these bacteria in the intestines determine proper function of intestinal barrier and immunity against pathogens, as well as prevent against inflammation and gastroenteritis $[7,31]$. Unfortunately, only $28 \%$ of the respondents declared they consume dairy products every day. At the same time it was noted that as many as $30 \%$ of people choose sweetened milk drinks several times a week, and $21 \%$ - every day. Such products are highly processed and often contain glucose-fructose syrup. Fructose is a simple sugar, which in glucose metabolism bypasses the stage catalysed by phosphofructokinase. This in turn leads to elevated synthesis of fatty acids and higher release of VLDL, which can increase the concentration of triacylglycerols and LDL cholesterol in blood. Studies on rats also indicate on harmful results of excessive intake of this sweetening agent. It facilitates the accumulation of visceral fatty tissue [8], development of insulin resistance, increases the risk of type 2 diabetes, contributes to the formation of lipids disorders and increases the risk of non-alcoholic liver disease [30].

\section{CONCLUSIONS}

1. Numerous dietary mistakes made by the patients contributed to a high extent to their problem with obesity.

2. The patients preparing for the surgery should especially resign from the consumption of beer and spirits, sweetened dairy products, sweets and animal fats with high melting temperature (lard, ba- 
con) to facilitate the reduction of liver volume, which is necessary before the procedure.

3. Frequency of consumption of selected products is correlated with socioeconomic status of the patients. It also depends on age, body mass and anthropometric indexes (BMI and WHR).

4. Obese patients qualified for the procedure should obtain the support of a dietician and a psychologist in order to introduce a balanced diet. It is necessary on every stage of preparation for the procedure and also for maintaining reduced body mass after the surgery, later in life.

\section{Ethical approval}

The study received the acceptance of the Bioethical Commission at Pomeranian Medical University, Szczecin, Poland

\section{Disclosure}

Authors report no conflict of interest.

\section{REFERENCES}

1. Arranz S, Chiva-Blanch $G$, Valderas-Martínez $P$, Medina-Remón A, Lamuela-Raventós $R$, Estruch $R$ : Wine, beer, alcohol and polyphenols on cardiovascular disease and cancer. Nutrients. 2012; 4(7): 759-781 doi: 10.3390/nu4070759.

2. Beford ChA, Nazir N, Perri MG: Prevalence of obesity among adults from rural and urban areas of the unites states: findings from NHANES (2005-2008). The J Rural Health. 2012; 28(4): 392-397 doi: 10.1111/j.17480361.2012.00411.x.

3. Boniecka I, Szczygiel B, Paśnik K: Wybrane cechy trybu życia pacjentów z otyłością olbrzymią zakwalifikowanych do operacji bariatrycznych [Selected lifestyle characteristic of patients with extreme obesity qualified for bariatric surgery]. Roczn Państ Zakł Hig. 2009; 60(3): 279-284 (in Polish).

4. Buckley JD, Howe PRC: Long-chain omega-3 polyunsaturated fatty acids may be beneficial for reducing obesity. Nutrients. 2010; 2(12): 1212-1230 doi: 10.3390/nu2121212.

5. Budżety gospodarstw domowych w 2016r. Główny Urząd Statystyczny [Household budgets in 2016. Central Statistical Office]. Available: https://statgovpl/ obszary-tematyczne/warunki-zycia/dochody-wydatkii-warunki-zycia-ludnosci/budzety-gospodarstwdomowych-w-2016-r-,9,11html (Accessed 04.07.18 in Polish)

6. Cichoż-Lach H, Grzyb M, Celiński K, Słomka M: Nadużywanie alkoholu a alkoholowa choroba wątroby [Alcohol abuse and alcoholic liver disease]. Alkoh Narkom. 2008, 21(1): 55-62 (in Polish).

7. de Oliveira Leite AM, Miguel MAL, Peixoto RS, Rosado AS, Silva JT, Paschoalin VMF: Microbiological, technological and therapeutic properties of kefir: a natural probiotic beverage. Braz J Microbiol. 2013; 44(2): 341349 doi: 10.1590/S1517-83822013000200001.
8. Ferder L, Ferder MD, Inserra F: The role of highfructose corn syrup in metabolic syndrome and hypertension. Curr Hypertens Rep. 2010; 12(2): $105-$ 112 doi: 10.1007/s11906-010-0097-3.

9. Hollcender P, Ross A, Kristensen M: Whole-grain and blood lipid changes in apparently healthy adults: a systematic review and meta-analysis of randomized controlled studies. Am J Clin Nutr. 2015; 102(3):556572 doi: 10.3945/ajcn.115.109165.

10. Jandhyala SM, Talukdar R, Subramanyam Ch, Vuyyuru $H$, Sasikala $M$, Reddy DN: Role of the normal gut microbiota. World J Gastroenterol. 2015; 21(29): 87878803 doi: 10.3748/wjg.v21.i29.8787.

11. Jastrzębska-Mierzyńska M, Ostrowska L, Hady R, Dadan J: Assessment of dietary habits, nutritional status and blood biochemical parameters in patients prepared for bariatric surgery: a preliminary study. Wideochir Inne Tech Maloinwazyjne. 2012; 7(3): 156-165 doi: 10.5114/wiitm.2011.27581.

12. Jastrzębska-Mierzyńska M, Ostrowska L, Wasiluk D, Konarzewska-Duchnowska E: Dietetic recommendations after bariatric procedures in the light of new guidelines regarding metabolic and bariatric surgery. Rocz Panstw Zakl Hig. 2015; 66(1): 13-19.

13. Kaniewska E, Gaździńska A, Jagielski P, Gaździński $S$, Wyleżot $M$ : Ocena częstotliwości spożycia wybranych produktów spożywczych przez chorych zakwalifikowanych do zabiegowego leczenia otyłości [Assessment of selected food intake frequency in obese patients qualified for bariatric surgery]. Hyg Pub Health. 2016; 51(1): 66-70 (in Polish).

14. Karbowska J, Kochan Z: Leptyna jako hormon łączący otyłość z dysfunkcją mięśnia sercowego [Leptin as a mediator between obesity and cardiac dysfunction]. Postepy Hig Med Dosw (online). 2012; 66: 267-274 (in Polish).

15. Karl JP, Saltzman E: The role of whole grains in body weight regulation. Adv Nutr. 2012; 3(5): 697 - 707 doi: 10.3945/an.112.002782.

16. Karwowska Z, Majchrzak K: Wpływ błonnika na zróżnicowanie mikroflory jelitowej (mikrobiota jelit) [The effect of dietary fibre on the diversity of intestinal microbiota]. Bromat Chem Toksykol. 2015; 48(4): 701 - 709 (in Polish).

17. Kłósek P: Rola stresu psychologicznego w neuroendokrynnej regulacji pobierania pokarmu i powstawaniu otyłości The role of psychological stress in the neuroendocrine regulation of food intake and obesity]. Forum Zaburzeń Metabol. 2016; 7(3):111-118 (in Polish).

18. Kłosiewicz-Latoszek L: Otyłość jako problem społeczny, zdrowotny i leczniczy [Obesity as a social, medical and therapeutic problem]. Probl Hig Epidemiol. 2010; 91(3): 339-343 (in Polish).

19. Kochan Z, Karbowska J, Babicz-Zielińska E: Trans kwasy thuszczowe w diecie - rola w rozwoju zespołu metabolicznego [Dietary trans-fatty acids and metabolic syndrome]. Postepy Hig Med Dosw (online). 2010; 64: 650-658 (in Polish).

20. Kostecka $M$, Bojanowska $M$ : Problems in bariatric patient care - challenges for dieticians. Wideochir Inne Tech Maloinwazyjne. 2017; 12(3): 207-215 doi: 10.5114/wiitm.2017.70193. 
21. Kryska S, Grajek M: Biopsychospołeczne znaczenie hiperfagii [Biopsychosocial determinants of hyperphagia]. JEcolHealth. 2013; 17: 178 - 185 (in Polish).

22. Kuczyńska B, Biczysko M, Bogdański P: Chirurgiczne leczenie otyłości olbrzymiej i zaburzeń metabolicznych [Surgical treatment of morbid obesity and mtabolic disorders]. Forum Zaburzeń Metabol. 2012; 3(2): 61-69 (in Polish).

23. Marlicz W, Ostrowska L, Łoniewski I: The role of gut microbiota in weight management by non-invasive interventions and bariatric surgery. Nutrition, Obesity \& Metabolic Surgery. 2014; 1(1): 20-29.

24. McKeown NM, Troy LM, Jacques PF, Hoffmann $U$, O'Donnell CJ, Fox CS: Whole- and refined-grain intakes are differentially associated with abdominal visceral and subcutaneous adiposity in healthy adults: the Framingham Heart Study. Am J Clin Nutr. 2010; 92(5): 1165-1171 doi: 10.3945/ajen.2009.29106.

25. Neubauer K, Poniewierka E: Błonnik w wybranych chorobach układu pokarmowego [Fiber in the gastrointestinal diseases]. Piel Zdr Publ. 2013; 3(3): 299-302 (in Polish).

26. Ostrowska L, Czapska D, Stefańska E, Karczewski J, Wyszyńska U: Czynniki ryzyka kamicy żółciowej u osób otyłych i z należną masą ciała [Cholecystolithiasis risk factors at obesity and normoweight persons]. Rocz Panstw Zakl Hig. 2005; 56(1):67-76 (in Polish).

27. Piekarzewska M, Wieczorkowski R, ZajenkowskaKozłowska A: Stan Zdrowia Ludności Polski w 2014 r. [Health condition of Polish people in 2014]. Główny Urząd Statystyczny Warszawa Zakład Wydawnictw Statystycznych. 2016 ISBN 978-83-7027-611-9 Strona 76 (in Polish).

28. Riccardi G, Rivellese AA, Giacco R.: Role of glycemic index and glycemic load in the healthy state, in prediabetes, and in diabetes. Am J Clin Nutr. 2008;87(1): 269-274 doi: 10.1093/ajen/87.1.269S.

29. Różnice w wynagrodzeniach kobiet i mężczyzn w Polsce. Główny Urząd Statystyczny [Differences in salary of women and men in Poland. Central Statistical Office]. Available:https://statgovpl/files/gfx/ portalinformacyjny/pl/defaultaktualnosci/5474/12/1/1/ roznice_w_wynagrodzeniach_i_kobiet_i_ mezczyzn_w_2014pdf(Accessed 04.07.18 in Polish).

30. Sadowska J, Rygielska M.: Technologiczne i zdrowotne aspekty stosowania syropu wysokofruktozowego do produkcji żywności [Technological and health aspects of using high fructose syrup in food production]. Żywn Nauka Technol Jakość. 2014; 3(94): 14 - 26 (in Polish). 31. Singh RK, Chang HW, Yan D, Lee KM, Ucmak D, Wong K, Abrouk M, Farahnik B, Nakamura M, Zhu $T H$, Bhutani T, Liao $W$ : Influence of diet on the gut microbiome and implications for human health. J Transl Med. 2017, 15(1):73 doi: 10.1186/s12967-017-1175-y.

32. Socha P, Wierzbicka A, Neuhoff-Murawska J, Włodarek $D$, Podleśny J, Socha J: Nonalcoholic fatty liver disease as a feature of the metabolic syndrome. Rocz Panstw Zakl Hig 2007; 58(1):129-137.

33. Sola M, Gajewska E, Manikowski W: Wpływ otyłości na jakość życia związana ze stanem zdrowia wśród dziewcząt i chłopców [The influence of obesity on health-related quality of life among girls and boys]. Nowiny Lek. 2012; 81(4): 321-329 (in Polish).

34. Stepniak U, Micek A, Waśkiewicz A, Bielecki W, Drygas W, Janion M, Kozakiewicz K, Niklas A, Puch-WalczakA, Pajak A: Prevalence of general and abdominal obesity and overweight among adults in Poland. Results of the WOBASZ II study (2013-2014) and comparison with the WOBASZ study (2003-2005). Pol Arch Med Wewn. 2016; 126(9): 662-671 doi: 10.20452/pamw.3499.

35. Szczepańska E, Brończyk-Puzoń A: Ocena nawyków żywieniowych pacjentów z otyłością, zakwalifikowanych do zabiegu bariatrycznego [Evaluation of nutritional habits of obese patients qualified for bariatric surgery]. Med Og Nauki Zdr. 2014; 20(3): 330-334 (in Polish).

36. Szymocha M, Bryła M, Maniecka-Bryła I: Epidemia otyłości w XXI wieku. [The obesity epidemic in the $21 \mathrm{st}$ century]. Zdr Publ. 2009; 119(2):207-212 (in Polish).

37. Trompette A, Gollwitzer ES, Yadava K, Sichelstiel AK, Sprenger M, Ngom-Bru C, Blanchard C, Junt T, Nicod LP, Harris NL, Marsland BJ: Gut microbiota metabolism of dietary fibre influences allergic airway disease and haematopoiesis. Nat Med. 2014; 20(2): 159-166 doi: 10.1038/nm.3444.

38. Wang Y, Beydoun BA, Liang L, Caballero B, Kumanyika $S K .:$ Will All Americans Become Overweight or Obese? Estimating the Progression and Cost of the US Obesity Epidemic. Obesity. 2008; 16(10): 2323-2330 doi: 10.1038/oby.2008.351.

39. World Health Organization. Available: http://wwwwhoint/ mediacentre/factsheets/fs311/en/ (Accessed 11.02.2018).

Received: 14.11.2018

Accepted: 04. 02.2019

This article is available in Open Access model and licensed under a Creative Commons Attribution-Non Commercial 3.0.Poland License (CC-BY-NC) available at: http://creativecommons.org/licenses/by-nc/3.0/pl/deed.en 